\title{
Restructuring non-performing loans for bank recovery: private workouts and securitisation mechanisms
}

Article

Accepted Version

Miglionico, A. (2019) Restructuring non-performing loans for bank recovery: private workouts and securitisation mechanisms. European Company and Financial Law Review, 16 (6). pp. 746-770. ISSN 1613-2556 doi: https://doi.org/10.1515/ecfr-2019-0026 Available at https://centaur.reading.ac.uk/88029/

It is advisable to refer to the publisher's version if you intend to cite from the work. See Guidance on citing.

To link to this article DOI: http://dx.doi.org/10.1515/ecfr-2019-0026

Publisher: De Gruyter

All outputs in CentAUR are protected by Intellectual Property Rights law, including copyright law. Copyright and IPR is retained by the creators or other copyright holders. Terms and conditions for use of this material are defined in the End User Agreement.

www.reading.ac.uk/centaur 
Central Archive at the University of Reading

Reading's research outputs online 


\title{
Restructuring non-performing loans for bank recovery: Private workouts and securitisation mechanisms
}

\author{
by
}

Andrea Miglionico*

\begin{abstract}
Resolving regimes of non-performing loans (NPLs) have raised concerns among supervisory authorities and banking regulators. NPLs play a central role in the linkages between poor lending and credit risks. This has implications for the management of asset quality and for the stability of the firm and the financial sector. A high stock of NPLs is undesirable to investors which can lead a decrease in the stock price, profitability loss and potentially to a distressed scenario. In the aftermath of the global crisis, the early resolution of NPLs requires coordinated insolvency proceedings and harmonised restructuring tools. The EU legislation introduced minimum loss coverage layers of capital for NPLs to address newly formed losses. Specifically, the supervisory toolkit implemented in the European Banking Union aims to improve the classification of loan quality and establish common practices to monitor non-performing exposures. This article argues that there is a need to enhance private arrangements within the resolution of distressed debts - alternative to public support such as asset management companies and securitisation mechanisms - which in turn would make it more manageable to reduce the NPL on banks' balance sheet.
\end{abstract}

\section{Table of Contents}

I. Introduction......................................................

II. The provisioning of NPLs.....................................6

III. The regulatory framework.......................................8

IV. The accounting standards of NPLs.............................. 12

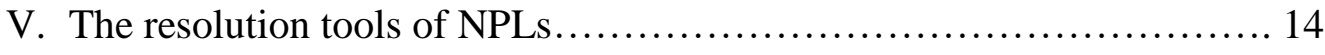

VI. The restructuring of NPLs: the case of Italian securitisation mechanism...16

VII. Conclusion....................................................22 


\section{Introduction}

In the aftermath of the global financial crisis (GFC) a degree of standardisation on the liability side of banks and other credit institutions has been developed among regulators and public authorities. ${ }^{1}$ However, the level of nonperforming loans (NPLs) across firms has become a major concern for countries with fragile economies and financial instability because the definition of NPLs vary across time, regulatory jurisdiction and legal system. ${ }^{2}$ This might specify different standards of how long repayment of interest and principal is past due; specify different recovering tools for distressed loans; consider non-performing exposures (NPEs) such as debt securities and off-balancesheet debt instruments; include or exclude securitised liabilities. ${ }^{3}$ The banking sector experienced a rapid rise in bad loans and defaults driven by the limitations of the Basel rules, i.e. the adequacy of capital, and the lack of convergence among supervisory authorities at the EU level. ${ }^{4}$ The NPLs played a central role in the linkages between poor lending and liquidity shortage: they create potential systemic shock in the markets because of the effect to trigger the credit risk. ${ }^{5}$ The regulatory interventions to evaluate the credit losses highlight the lack of common standards to monitor NPLs and the fragility of the banking institutions to assess the loan origination and borrowers' creditworthiness. $^{6}$

(*) Lecturer, University of Reading, School of Law. E-mail: a.miglionico@ reading.ac.uk. The author is grateful to the anonymous reviewers for the useful comments provided on an early draft. Any errors or omissions remain the sole responsibility of the author.

\footnotetext{
${ }^{1}$ Basel Committee on Banking Supervision, "Prudential treatment of problem assets - definitions of nonperforming exposures and forbearance", Guidelines (4 April 2017), 6-7, <http://www.bis.org/bcbs/publ/d403.htm> (accessed 29 July 2019).

${ }^{2}$ Mwanza Nkusu, "Nonperforming Loans and Macrofinancial Vulnerabilities in Advanced Economies", IMF Working Paper (July 2011), 4.

${ }^{3}$ EBA, "Guidelines on credit institutions' credit risk management practices and accounting for expected credit losses", Final Report EBA/GL/2017/06 (2017),

<https://www.eba.europa.eu/documents/10180/1842525/Final+Guidelines+on+Accounting+for+Expec ted+Credit+Losses+\%28EBA-GL-2017-06\%29.pdf> (accessed 28 July 2019).

${ }^{4}$ Marco Lamandini/Giuseppe Lusignani/David Ramos Munoz, "Does Europe Have What It Takes to Finish the Banking Union”, Columbia Journal of European Law 24 (2018), 260.

5 Giulio Bottazzi/Alessandro De Sanctis/Fabio Vanni, "Non-performing loans, systemic risk and resilience in financial networks", LEM Working Paper Series, No. 2016/08 (March 2016), 2-3, <https://www.econstor.eu/bitstream/10419/174517/1/2016-08.pdf> (accessed 27 July 2019).

${ }^{6}$ Marcel Magnus/Jérôme Deslandes/Cristina Dias, "Non-performing loans in the Banking Union Stocktaking and challenges", European Parliament (October 2018), 7-8, <http://www.europarl.europa.eu/RegData/etudes/BRIE/2018/614491/IPOL_BRI\%282018\%29614491_ EN.pdf> (accessed 29 July 2019).
} 
A non-performing loan is defined as a sum of borrowed money upon which the debtor has not made his or her scheduled payments for at least 90 days although there is no consensus on the exact definition of NPL. Generally, at some point after the debtor starts making payments again on a NPL, it becomes a re-performing loan, even if the debtor has not caught up on all the missed payments. According to the new accounting rules of IFRS $9^{7}$ provisioning should be more forward-looking and that, in retrospect, credit events should be recognised before they occurred to better prepare banks for losses when they realised. ${ }^{8}$ The current regulatory approach to NPLs classification gives firms a wide degree of discretion and the practical implementation of rules depends much on domestic enforcement system.

The main problem is the lack of a harmonised framework to assess the obligors' ability to repay and whether it has become non-performing. ${ }^{9}$ The European Central Bank (ECB) has focused in creating a common classification of the asset quality standard that should complement a classification of sources of banks' funding, i.e. equity and debt, and has enhanced ad hoc resolving options to deal with NPLs swiftly, for example securitisation schemes in some EU countries (e.g. Italy and Greece). ${ }^{10}$ In parallel, the Commission has adopted a set of regulatory measures to reduce the level of bad loans and strengthen the lending system in the Eurozone. ${ }^{11}$ NPLs have become a persistent phenomenon in financial institutions and have dragged on economic activity, especially for countries that rely mainly on bank financing, as is the case in the euro area. ${ }^{12}$ The Italian banking sector reported an outstanding stock of $€ 189$ billion of

\footnotetext{
${ }^{7}$ The IFRS 9 accounting rules establish a 'forward-looking' approach in the early recognition and provisioning of NPLs.

${ }^{8}$ Samuel Knott/Peter Richardson/Katie Rismanchi/Kallol Sen, "Understanding the fair value of banks' loans", Bank of England Financial Stability Paper No 31 (November 2014), 7, <https://www.bankofengland.co.uk/-/media/boe/files/financial-stability-paper/2014/understanding-thefair-value-of-banks-loans> (accessed 27 July 2019).

${ }^{9}$ David Bholat/Rosa M. Lastra/Sheri M. Markose/Andrea Miglionico/Kallol Sen, "Non-performing loans at the dawn of IFRS 9: regulatory and accounting treatment of asset quality", Journal of Banking Regulation 19 (2018), 35-36.

${ }^{10}$ European Central Bank, "Stocktake of national supervisory practices and legal frameworks related to NPLs" (September 2016), 52 and 85-86,

<https://www.bankingsupervision.europa.eu/legalframework/publiccons/pdf/npl/stock_taking.en.pdf > (accessed 12 October 2019).

${ }^{11}$ European Commission, "Communication from the Commission: Completing the banking union" $\operatorname{COM}(2017) 592$ final, 6, <https://ec.europa.eu/finance/docs/law/171011-communication-bankingunion_en.pdf> (accessed 12 October 2019).

${ }^{12}$ International Monetary Fund, "A Strategy for Resolving Europe's Problem Loans", Staff Discussion Note, SDN/15/19 (2015), 9, <https://www.imf.org/external/pubs/ft/sdn/2015/sdn1519.pdf> (accessed 29 July 2019).
} 
gross NPLs mostly accumulated during the financial and sovereign debt crisis. ${ }^{13}$ In Italy important reforms changed the procedures for firms' liquidation, restructuring and for the foreclosure of assets. ${ }^{14}$ Specifically, the Italian government has taken initiatives concerning NPL recovery such as public guarantee schemes and banks' workout mechanisms. $^{15}$

In Greece, Law No 4354/2015 regulates the assignment and the transfer of nonperforming loan claims. ${ }^{16}$ This legislation provides specific rules on: (1) obtaining a license from the Bank of Greece for Debt Management Companies and Debt Transfer Companies (DTCs) for NPLs; (2) the agreements assigning the management of claims; and (3) the sale and transfer of claims from NPLs and credit agreements. The law adopts a 90 day past due threshold to define non-performing assets however the NPL figures do not provide information about the level of provision held against these loans by banks. In addition, the Bank of Greece has introduced supervisory practices and guidelines for the management of NPLs requiring banks to implement resolution procedures with distressed borrowers and standardise the loan workout process. ${ }^{17}$ In this context, the Commission has recently approved the Greek plan to establish an asset protection scheme ("Hercules") to reduce the amount of NPLs in the banking system without State aid intervention. ${ }^{18}$ The scheme aims to support banks in managing NPLs under market conditions: it is a private solution mechanism in which a securitisation vehicle will buy non-performing loans from the bank and sell notes to investors. The

\footnotetext{
${ }^{13}$ Bank of Italy, "Financial Stability Report", No. 1 (May 2019), 25-26. It is reported that the coverage ratio - provisions in relation to the whole stock of NPLs - reached 52.7 percent.

${ }^{14}$ Luisa Carpinelli/Giuseppe Cascarino/Silvia Giacomelli/Valerio Vacca, "The management of nonperforming loans: a survey among the main Italian banks", Bank of Italy Occasional Papers No 311, (February 2016), 8, <http://ssrn.com/abstract=2838708> (accessed 12 October 2019). See also Anke Weber, "Bank Consolidation, Efficiency, and Profitability in Italy", IMF Working Paper WP/17/175 (2017), 9.

${ }^{15}$ Luca Ciavoliello/Federica Ciocchetta/Francesco Maria Conti/Igino Guida/Anna Rendina/Giovanni Santini, "What's the value of NPLs?", Bank of Italy Notes on Financial Stability and Supervision No. 3 (2016), 9.

${ }^{16}$ Law 4354/2015, "Non-performing loans management, wage provisions, and other urgent provisions concerning the implementation of the fiscal goals and structural reforms agreement" (Government Gazette A'176).

17 See the Executive Committee Act (ECA) No 42/2014 on the supervisory framework for nonperforming exposures (NPEs), thus introducing a harmonized framework and accelerating efforts of banks regarding efficient NPE management. See also the ECA No 47/2015 establishing a comprehensive prudential reporting framework for NPEs in Greece; and the Code of Conduct on NPL management by virtue of Decision 116/25.8.2014 issued by the Bank of Greece Credit and Insurance Committee according to Law 4224/2013.

${ }^{18}$ European Commission, "State aid: Commission approves market conform asset protection scheme for banks in Greece", IP/19/6058, (10 October 2019),

<https://ec.europa.eu/commission/presscorner/detail/en/IP_19_6058> (accessed 19 October 2019).
} 
State will provide a guarantee for the senior tranche of the notes in exchange of a remuneration at market terms. Basically, the State guarantee becomes effective if more than half of the non-guaranteed riskier tranches have been successfully sold to private investors. The State receives the fee remuneration on a market benchmark: this mechanism should increase the efficiency of the NPLs workout and recovery. In order to address different domestic approaches to deteriorated assets, the EU legislation has adopted the Directive No 1023 of 2019 that provides a degree of harmonisation for restructuring distressed debts with the aim to improve the management tools of NPLs. ${ }^{19}$

This article argues that NPLs represent a systemic threat for the banking sector due to the lack of common regulatory standards and harmonised insolvency proceedings. On this view, NPLs can determine negative externalities on the banking system by depriving stock prices and depressing economic growth. This article examines the restructuring tools for NPLs and suggests that the early identification of which loans are nonperforming requires standardisation of the loan portfolio and timely assessment of exposures.

The next section discusses the role of NPLs in the bank's balance sheet under distressed scenario. While higher ex-ante provisioning against expected loan losses lowers bank profitability in the short term, over the long term the constitution of loan loss provisions (LLPs) in good times reduces the chances of having a situation in crisis times where ex-post NPL losses force a bank to raise capital. Forward-looking provisioning and recognition of loss represent the main challenges for regulators in terms of banking recovery and financial stability. The consequence of insufficient loan loss provisioning and the accumulation of NPLs is the combined threat of a capital default and a credit shortage. Section three examines the legislative framework of NPLs in the light of the reforms adopted by the global regulators to tackle the negative impact on lending to the banking system. Section four addresses the accounting practices for NPLs across jurisdictions. The focus is on current differences of prudential treatment among supervisors in terms of enforcement of NPL. Section five analyses the resolution tools for non-performing exposures and argues that the objectives to reduce the public

\footnotetext{
${ }^{19}$ See Recital 3 to Directive No 1023 of 2019 on preventive restructuring frameworks, on discharge of debt and disqualifications, and on measures to increase the efficiency of procedures concerning restructuring, insolvency and discharge of debt, and amending Directive (EU) 2017/1132 that provides "the availability of effective preventive restructuring frameworks would ensure that action is taken before enterprises default on their loans, thereby helping to reduce the risk of loans becoming non-performing in cyclical downturns and mitigating the adverse impact on the financial sector".
} 
intervention in failing banks constitute a recurrent challenge in the financial markets. Section six considers the securitisation mechanisms of NPLs and suggests that the system of State guarantees to restructure troubled assets can be seen as a legacy of bailout programmes. The last section concludes.

\section{The provisioning of NPLS}

The problems NPLs create for banking recovery are evident in the period since the start of the GFC with the persistence of distressed loans being a reason for the fragility of banking sector. Rottke and Gentgen noted that 'while non-performing loans are a phenomenon that is permanently present in the balance sheets of banks and other lending institutions, the significant rise of non-performing loans in banks' balance sheets and the emergence of a non-performing loan market are a temporary phenomenon'. ${ }^{20} \mathrm{~A}$ loan is considered non-performing when customer's payments are past due: this is can be interpreted as an early warning signal of banking crisis however the loan classification represents a key indicator of the bank's credit quality. ${ }^{21}$

The fundamental problem is that the balance sheet counterpart of NPLs on the assets side is an eventual hit to bank capital on the claims side: one key ratio to track is the proportion of LLPs to NPLs (coverage ratio) constructed and commonly used by credit rating agencies. ${ }^{22}$ The coverage ratio measures the provisioning of bad loans and the ability for banks to recover unexpected losses. The aim should be having a level of provisioning commensurate with the initial expectations of recovery on loans. ${ }^{23}$ If this is not so, then the scale of losses may be so large that they cannot be covered by income, bringing a bank's capital below or close to the minimum required. At that point, banks might have to recapitalise when the system may be facing a distressed scenario where it is difficult for a bank to raise capital as profitability is deteriorating and general economic conditions are weak. Demertzis and Lehmann argued that 'efforts to reduce

\footnotetext{
${ }^{20}$ Nico B. Rottke/Julia Gentgen, "Workout management of non-performing loans: A formal model based on transaction cost economics", Journal of Property Investment \& Finance 26 (2008), 59-60.

${ }^{21}$ Karlo Kauko, "External deficits and non-performing loans in the recent financial crisis", Economics Letters 115 (2012), 196.

${ }^{22}$ Anne Beatty/Liao Scott, "Do delays in expected loss recognition affect banks' willingness to lend?", Journal of Accounting and Economics 52 (2011), 19-20.

${ }^{23}$ It can be observed that for collateralised lending, provisions under US GAAP and IFRS are net of the recoveries on liquidating collateral: when the provisions are compared to the gross amount of the nonperforming loan, they can be adequate even if less than 100 percent if there is adequate collateral.
} 
and remove NPLs from the balance sheets of creditors must simultaneously remove excess debt from the balance sheets of debtors'. ${ }^{24}$ However adequate provisioning for NPLs requires overcoming complex strategic incentives that banks have in either wanting to keep LLPs low, or for not writing NPLs off from their balance sheets.

The timing of losses taken as a result of provisions or write offs, and the level of loan loss provisions set aside for future NPLs on the balance sheet, are often part of a bank's strategy to smooth reported earnings and reported capitalisation. ${ }^{25}$ Specifically, the Basel Common Equity Tier 1 and Tier 1 capital adequacy ratio numerators include common stock and retained earnings. If higher LLPs are taken as losses reducing retained earnings this can determine a trade-off between reporting higher Common Equity Tier 1 and Tier 1 capital ratios and maintaining adequate LLPs. This trade-off is complicated by a Basel III Common Equity Tier 1 (CET1) capital requirement of 7\% (comprising the minimum CET1 requirement of $4.5 \%$ plus a mandatory capital conservation buffer of $2.5 \%$ ) of risk-weighted assets, with further buffers added to the CET1 requirement in specific cases. ${ }^{26}$ In this context, LLPs have the effect of reducing CET1 and therefore the numerator of those ratios. ${ }^{27}$

Since write offs mean that some loans and the provisions against them disappear from the balance sheet - and as some loans tend to have higher provisions raised against them as a proportion of the gross amount of the loan - it follows that a bank that elected to write off relatively more of its highly provisioned problem loans would show lower provisions as a percentage of overall loans. Full information about write offs, and further data on when a bank deems that such write offs take place, are critical for users of financial statements to compare overall provision numbers from bank to bank. Jassaud and Kang argued that these banks have delayed writing off highly provisioned loans as this would lower their overall provisioning ratio and possibly their credit

\footnotetext{
${ }^{24}$ Maria Demertzis/Alex Lehmann, “Tackling Europe's crisis legacy: a comprehensive strategy for bad loans and debt restructuring", Bruegel Policy Contribution No 2017/11 (2017), 1, <https://www.econstor.eu/bitstream/10419/173107/1/PC-11-2017.pdf> (accessed 29 July 2019).

${ }^{25}$ Iftekhar Hasan and Larry D. Wall, "Determinants of the Loan Loss Allowance: Some Cross-Country Comparisons", Financial Review 39 (2004), 151-152. See also Paul Beck/Ganapathi Narayanamoorthy, "Did the SEC impact banks' loan loss reserve policies and their informativeness?", Journal of Accounting and Economics 56 (2013), 42.

${ }^{26}$ Josè Gabilondo, Bank Funding, Liquidity, and Capital Adequacy. A Law and Finance Approach, 2016 p. 102-103.

${ }^{27}$ The precise effect or size of the reduction is indicated by the interaction of the accounting rules on provisioning with the capital framework.
} 
rating. ${ }^{28}$ The International Accounting Standards (IAS 39) was not explicit on exactly when and how to write off uncollectible loans: in this case, the more LLPs and related accounting policy decisions such as write-offs are left to management discretion, the more difficult it becomes to compare cross-firm and cross-border NPL and LLP figures. $^{29}$

\section{The regulatory framework}

The definition of bank capital under Basel rules has significantly contributed to the development in the assessment of the loan quality although substantive progress requires on consolidating the classification of asset in the balance sheet. ${ }^{30}$ However the lack of a common level playing field for NPLs makes meaningful comparison of banks' assets difficult for investors and regulators. The UN System of National Accounts provides a global statistical definition of NPLs as "a loan is non-performing when payments of interest or principal are past due by 90 days or more, or interest payments equal to 90 days or more have been capitalised, refinanced, or delayed by agreement, or payments are less than 90 days overdue, but there are other good reasons (such as a debtor filing for bankruptcy) to doubt that payments will be made in full". ${ }^{31}$

The Basel Committee on Banking Supervision (BCBS) published guidelines in evaluating credit risk for regulatory purposes. ${ }^{32}$ Under the Basel II capital framework, the internal ratings-based (IRB) approach required credit firms to provide own assessments of probability of default, loss given default and exposure at default. ${ }^{33}$ Specifically, default is defined as where an obligor is 90 days past due, or is unlikely to

\footnotetext{
${ }^{28}$ Nadège Jassaud/Kenneth H Kang, “A Strategy for Developing a Market for Nonperforming Loans in Italy”, IMF Working Paper No. 15-24 (2015), 16.

${ }^{29}$ Provisions are no longer based on an "incurred loss" (IAS 39) approach (i.e. taken against loans where an objective 'loss event' has occurred) but are based on forward-looking rules (IFRS 9) that involve an assessment whether 'significant deterioration' has occurred.

${ }^{30}$ The definition of capital was first harmonised under the Basel I Accord of 1988 through a soft law instrument. See Basel Committee on Banking Supervision, "Report on International Convergence of Capital Measurement and Capital Standards" (July 1988), <https://www.bis.org/publ/bcbsc111.pdf> (accessed 27 July 2019).

${ }^{31}$ United Nations System of National Accounts 2008,

<https://unstats.un.org/unsd/nationalaccount/sna2008.asp> (accessed 28 July 2019). However the UN statistical definition of a non-performing loan leaves scope for firm discretion since the meaning of certain terms such as "objective evidence of impairment" are not precisely defined.

${ }^{32}$ Basel Committee on Banking Supervision, "Sound Practices for Loan Accounting and Disclosure", Basel Committee on Banking Supervision Paper (July 1999), 35, para 91.

${ }^{33}$ Basel Committee on Banking Supervision, "International Convergence of Capital Measurement and Capital Standards", Revised Framework (June 2004), 〈https://www.bis.org/publ/bcbs107.pdf> (accessed 29 July 2019).
} 
pay its credit obligations to the banking group in full, without recourse by the bank to actions such as realising security. In 2006 the BCBS issued guidance that mentioned loan classification recommending banks to implement asset quality system on the basis of credit risk. ${ }^{34}$ The BCBS also provided guidelines on prudential treatment of problem assets aiming to set a common definition for the terms 'non-performing loan' and 'forbearance'. ${ }^{35}$ The definition in this document applies to all credit exposures from onbalance sheet loans, including debt securities, and off-balance sheet items, such as loan commitments and financial guarantees. The definition of non-performing developed for this purpose combines three existing concepts: (1) all exposures defined as in default under the Basel definition quoted above are considered non-performing; (2) exposures determined to be impaired for accounting purposes are defined as non-performing; and (3) loans that are past due by 90 days or where it is determined that full repayment is unlikely ${ }^{36}$ are also considered non-performing.

The BCBS clarifies that collateralisation does not influence past due status and should not be considered in the categorisation of non-performing exposures ${ }^{37}$ It also defines forbearance as "a concession granted by a bank to a counterparty for reasons of financial difficulties that would not be otherwise considered by the lender". 38 Forbearance comprises concessions extended to any exposures in the form of a loan, a debt security or an off-balance-sheet item due to the position of the counterparty. This definition covers exposures of performing and non-performing status before the granting of forbearance measures. The main purpose of the BCBS guidance is to ensure a harmonised approach to the disclosure of modified loans and debt securities due to

\footnotetext{
${ }^{34}$ Basel Committee on Banking Supervision, "Sound credit risk assessment and valuation for loans", June 2006, <https://www.bis.org/publ/bcbs126.pdf> (accessed 27 July 2019). In a further Consultative Document issued in December 2014 on revisions to the standardised approach for credit risk, the BCBS suggested a definition of non-performing, whose threshold includes (amongst other criteria) 90 days past due for loans, and 30 days past due for securities. The purpose of these criteria is to calculate a 'nonperforming asset' (NPA) ratio when assessing exposures to other banks. At the time of issue, the proposals in this consultation were described by the BCBS as "at an early stage of development".

${ }^{35}$ These new definitions are intended to complement existing accounting and regulatory measures and as reference points to promote comparability. See Basel Committee on Banking Supervision, "Prudential treatment of problem assets - definitions of non-performing exposures and forbearance", Guidelines (4 April 2017), <http://www.bis.org/bcbs/publ/d403.htm> (accessed 28 July 2019).

${ }^{36}$ This is similar to the definition developed by the European Banking Authority in the "Final implementing technical standards (ITS) on supervisory reporting on forbearance and non performing exposures under Article 99(4) of Regulation (EU) No 575/2013" published in 2014.

${ }^{37}$ The BCBS also notes that non-performing status should be applied at the level of the counterparty in the case of exposures to a non-retail counterparty, and at the level of each exposure in the case of exposures to a retail counterparty.

${ }^{38}$ Basel Committee on Banking Supervision (fn. 1), 7.
} 
the case of borrower's financial difficulties. ${ }^{39}$ The EU Regulation No 630/2019 on minimum loss coverage for non-performing exposures provides that "a forbearance measure granted to a non-performing exposure should not discontinue the classification of that exposure as non-performing unless certain strict discontinuation criteria are fulfilled". ${ }^{40}$ High percentages of NPLs reduce profitability, increase funding costs and tie up bank capital, which negatively impact credit supply and ultimately growth. Addressing the rise of NPLs has been under constant monitoring in the EU banking union and the supervision of deteriorated assets requires comprehensive action to deal with these types of bad loans sitting on banks' books. ${ }^{41}$ The ECB established a prudential regime to strengthen the capital rules and banking supervision since NPLs represent the major systemic threat that they are facing as they may rapidly lead to bank and borrower insolvencies. ${ }^{42}$

In March 2017 the ECB issued a qualitative guidance on non-performing loans, including consideration of how the 'unlikely to pay' criterion should be applied in practice and how banks should manage and monitor forbearance, write offs and collateral valuation. ${ }^{43}$ This supervisory toolkit aims to address the issue of identification and allocation of past due loans in the EU banking sector. The NPL guidance has been further developed in the prudential treatment for distressed assets through supervisory

\footnotetext{
${ }^{39}$ The BCBS recommends banks not to use forbearance practices to avoid classifying loans as nonperforming.

${ }^{40}$ See recital 7 in the preamble to Regulation (EU) No 630/2019 amending Regulation (EU) No 575/2013 as regards minimum loss coverage for non-performing exposures (OJ 2019 L 111, p. 4). For a commentary see Carla Stamegna, "Minimum loss coverage for non-performing loans", European Parliamentary Research Service (March 2019), 6, <https://epthinktank.eu/2019/03/11/minimum-losscoverage-for-non-performing-loans-eu-legislation-in-progress/> (accessed 14 October 2019).

${ }^{41}$ David Bholat/Rosa M. Lastra et al. (fn. 9), 9.

${ }^{42}$ The question of asset quality classification has become prominent since the divergence in practice between firms and regulators in defining "non-performing" has hampered the need for NPL harmonisation. Within the NPL category are comprised: (1) bad loans; (2) default loans; and (3) distressed debt. The classification depends on several factors and varies across jurisdictions. In some countries, nonperforming means that the loan is impaired while in others can mean that payments are past due. Nevertheless, a rather common feature of nonperforming loans appears to be that a payment is "more than 90 days" past due, especially for retail loans. The classification of the loan as non-performing by the bank and when the loan becomes "bad debt" depends on domestic regulations. Further, the rising discrepancy between banks' overdue loan ratios and NPL ratios makes difficult to identify deteriorated loans that are not formally classified as nonperforming. This problem is particularly evident in the Chinese banks where the fragility of loan loss provisions does not help to mitigate the NPL classification issue. See Yuan Yang, "China banks in stand-off with regulators on loan loss provisions", Financial Times, London, 30 October 2016.

43 ECB, "Guidance to banks on non-performing loans" (2017), 49-50, <https://www.bankingsupervision.europa.eu/ecb/pub/pdf/guidance_on_npl.en.pdf> (accessed 29 July 2019).
} 
expectations on the classification of NPEs. ${ }^{44}$ The ECB's supervisory expectations supplement the NPL guidance by specifying the regulatory actions when assessing a bank's levels of prudential provisions for NPEs. The ECB regulatory initiatives have been followed by the Commission's proposal for a regulation on a minimum loss coverage for NPEs adopted in March 2018 that complements the Capital Requirements Directive (CRD IV) ${ }^{45}$ and establishes a 'case-by-case' approach in the application of the prudential backstop for NPEs. ${ }^{46}$ Although the guidance can be considered a form of principles-based regulation ${ }^{47}$, these initiatives ensure substantial degree of harmonisation which permits international comparisons of the asset side, and both loan classification and the definition of NPLs. The gains from a harmonised approach would be to aid the comparability of firms, to quantify forbearance and have a better understanding of the relation between NPLs, economic growth and financial stability. There might be a role for more discretionary prudential policy since the international regulatory response to this issue has been concentrated to enhance the disclosure and provisioning. ${ }^{48}$ While the principles-based approach to loan classification has some benefit, it gives firms wide discretion in the way they account for impairment. It also gives domestic authorities wide discretion to restructure NPLs through government guarantees and State-backed plans. ${ }^{49}$ However, in the presence of a more prescriptive regime, the practical achievement of regulatory treatment depends on enforcement system.

\footnotetext{
${ }^{44}$ ECB, "Addendum to the ECB Guidance to banks on nonperforming loans: Prudential provisioning backstop for non-performing exposures" (2018), 2,

<https://www.bankingsupervision.europa.eu/ecb/pub/pdf/ssm.npl_addendum_201803.en.pdf > (accessed 28 July 2019).

${ }^{45}$ Directive 2013/36/EU of the European Parliament and of the Council of 26 June 2013 on access to the activity of credit institutions and the prudential supervision of credit institutions and investment firms, amending Directive 2002/87/EC and repealing Directives 2006/48/EC and 2006/49/EC. Article 104(1)(d) of the Directive states that '[...] competent authorities shall have the powers to require institutions to apply a specific provisioning policy or treatment of assets in terms of own funds requirements.'

${ }^{46}$ Commission's proposal for a regulation on a minimum loss coverage for non-performing exposures, Brussels COM(2018) 134 final.

${ }^{47}$ The NPL guidance contains soft law recommendations not binding and not enforceable that leave discretion to national authorities to implement them at the domestic level.

${ }^{48}$ International Monetary Fund, "A Strategy for Resolving Europe's Problem Loans", Staff Discussion Note, SDN/15/19 (2015), 9, <https://www.imf.org/external/pubs/ft/sdn/2015/sdn1519.pdf> (accessed 28 July 2019).

${ }^{49}$ Faidon Kalfaoglou, "NPLs resolution regimes: Challenges for regulatory authorities", Journal of Risk Management in Financial Institutions 11 (2018), 173.
} 
In the wake of the GFC, the lack of an internationally harmonised accounting concept of impairment determined a grey area with respect to forbearance and the restructuring of troubled loans. IAS 39 provided that restructuring is a credit event that might lead to impairment and impairments have to be calculated based on the difference between the original and modified conditions. ${ }^{50}$ The standard does not rule out cases of restructuring where there is no impairment and there is ambiguity about whether once restructured, so an exposure needs to continue being identified as impaired. ${ }^{51}$ On this view, it has been argued that 'lenders choose to extend or otherwise modify the terms of loans that show evidence of financial stress, these loans might avoid arrears and as such might not be identified as impaired (or non-performing), despite underlying credit deterioration of the borrower'. 52

In 2011 the UK Financial Services Authority issued a guidance on loan forbearance raising concerns that "certain accounting practices can have the effect of concealing the full effect of impairment and forbearance and thus may not present the true nature of credit risk within retail portfolios". ${ }^{53}$ In the US, the Financial Accounting Standards Board published guidelines on the definition of troubled debt restructurings with the aim of developing more consistent standards in determining whether a modification of a loan receivable constitutes a concession to a borrower that is experiencing financial difficulty. ${ }^{54}$ In Central, Eastern and Southeastern Europe (CESEE countries), the 'Vienna Initiative' - a private and public forum formed by international financial institutions, international organisations, public authorities and banks - has launched an action plan to establish a common platform to create the right conditions for Western

\footnotetext{
${ }^{50}$ Kees Camfferman, "The Emergence of the 'Incurred-Loss' Model for Credit Losses in IAS 39", Accounting in Europe 12 (2015), 17.

${ }^{51}$ Charles W. Calomiris/Stephen H. Haber, Fragile by Design: The Political Origins of Banking Crises and Scarce Credit, 2014, p. 4.

52 Shekhar Aiyar/Wolfgang Bergthaler/Jose Garrido/Anna Ilyina/Andreas Jobst/Kenneth Kang/Dmitriy Kovtun/Yan Liu/Dermot Monaghan/Marina Moretti, “A Strategy for Resolving Europe's Problem Loans", International Monetary Fund, Staff Discussion Note SDN/15/19 (September 2015), 5.

${ }^{53}$ Financial Services Authority, "Forbearance and Impairment Provisions - Mortgages", FSA Finalised guidance (October 2011), 23, <https://www.fca.org.uk/publication/finalised-guidance/fg11_15.pdf> (accessed 28 July 2019).

${ }^{54}$ Financial Accounting Standards Board, “Accounting Standards Update No. 2011-02, Receivables (Topic 310): A Creditor's Determination of Whether a Restructuring Is a Troubled Debt Restructuring”, April 2011, 1-2, <https://asc.fasb.org/imageRoot/05/7484705.pdf> (accessed 29 July 2019).
} 
banks to remain engaged in emerging Europe. ${ }^{55}$ The 'Vienna Initiative' aims to introduce coordinated resolution policies for dealing with distressed assets as NPLs are considered a serious obstacle to banking recovery. ${ }^{56}$ This can have macroeconomic consequences, as the burden of debt felt by some results in their decreasing spending, with reduced income down the line for others, including even those not indebted. ${ }^{57}$

In terms of accounting treatment of NPLs, regulators have been incentivised to delay the recognition of any losses until banks developed loan loss reserves. ${ }^{58}$ If there is a place for forbearance as a resolution or macro-prudential tool in certain circumstances to prevent the worst of economic catastrophes, this suggests that the search for a single, deterministic definition of non-performing loans is misconstrued. The focus of regulators should be on establishing a global standard NPL definition and on getting banks, regulators, investors and other stakeholders common procedures to monitor asset quality in a more timely and transparent way. ${ }^{59}$ On this point, the EBA produced the 'NPL transaction templates' in order to create comparable and standardised data on non-performing assets. ${ }^{60}$ The main objective is to address the information asymmetries in the NPLs transactions and reduce potential market failures deriving from the delay to restructure bad loans on time.

At origination, lenders collect information about obligors: in liquidation procedures, courts collect information about defaulted obligors. However in the interval in between, in the absence of market prices for non-traded loans, there is a need for continual monitoring of asset quality by looking at the overall solvency of obligors and the progress of projects the loans are financing. ${ }^{61}$ As regulatory standards shifted from

\footnotetext{
${ }^{55}$ European Bank Coordination Vienna Initiative, "Vienna Initiative pushes for action plan to deal with NPLs in central and south-eastern Europe. Fostering an effective framework for NPL restructuring and resolution", 26 September 2014, <http://vienna-initiative.com/wp-content/uploads/2014/10/NPL-PressRelease.pdf $>$ (accessed 28 July 2019).

56 James Roaf, "Non-Performing Loans in CESEE", 23 September 2014, <http://viennainitiative.com/wp-content/uploads/2014/11/Session-I-James-Roaf-IMF.pdf> (accessed 28 July 2019).

${ }^{57}$ Perry Mehrling, The new Lombard Street: How the Fed Became the dealer of last resort, 2010, p. 7.

${ }^{58}$ Piers Haben, "Standardising the definition of non-performing exposure and forbearance", EBA Case Study (2015), <http://docplayer.net/20943532-Case-study-standardising-the-definition-of-nonperforming-exposure-and-forbearance.html> (accessed 28 July 2019).

${ }^{59}$ Andrew Campbell, "Bank insolvency and the problem of nonperforming loans", Journal of Banking Regulation 9 (2007), 38. It is observed that 'the lack of an effective legal framework for bank insolvency has been a significant factor in many of the countries that have experienced regular banking crises and high levels of NPLs'.

60 European Banking Authority, "EBA NPL templates", 14 December 2017, <http://www.eba.europa.eu/-/eba-publishes-its-standardised-data-templates-as-a-step-to-reduce-npls> (accessed 29 July 2019).

${ }^{61}$ European Banking Authority, "Draft Guidelines on loan origination and monitoring”, Consultation Paper EBA/CP/2019/04 (19 June 2019), 34-36,
} 
incurred to expected loss models, it can be argued that substantial coordination among resolving tools represents a way forward to establish a harmonised insolvency regime for NPLs. ${ }^{62}$

\section{$V$. The resolution tools of NPLs}

Resolving the NPLs problem implies allocating losses within the system that should be borne either by banks' customers, banks themselves, investors or sovereigns. ${ }^{63}$ The fact that there is no accepted definition of NPL - as a sum of borrowed money upon which the debtor has not made his or her scheduled payments for at least 90 days - creates difficulty to assess the viable option to resolve deteriorated assets. ${ }^{64}$

Various proposals to resolve NPLs namely individual bank restructurings, bad-bank units and bank-specific asset management companies (AMCs) have been advanced among regulators. Enria suggested to establish an AMC with government support to deal with NPLs selling the assets at their economic value. ${ }^{65}$ Where AMCs are established to manage assets from banks the price for removing them is a critical operational issue that can delay restructurings where banks seek to avoid marking down their assets or transferring potential upside to a third party. ${ }^{66}$ Several issues raise around the AMC: political interference in the disposition and restructuring of assets, and lack of transparency with respect to all of its operations. These issues represent the main concerns for market actors since they can determine a pervasive intervention of State. ${ }^{67}$ In case of systemic crisis, the government may face the problem to provide solvency

\footnotetext{
<https://eba.europa.eu/documents/10180/2831176/CP+on+GLs+on+loan+origination+and+monitoring. pdf/3bc64e01-a4d1-4c7e-92d4-1dd84f4b234c> (accessed 27 July 2019).

${ }^{62}$ David M. Bholat, "The future of central bank data", Journal of Banking Regulation 14 (2013), 192.

63 Benoit Mesnard/Alienor Anne Claire Duvillet-Margerit/Cairen Power/Marcel Magnus, "Nonperforming loans in the Banking Union: stocktaking and challenges", European Parliament (18 March 2016), 4, <http://www.europarl.europa.eu/RegData/etudes/BRIE/2016/574400/IPOL_BRI(2016)574400_EN.pd $>$ (accessed 29 July 2019).

${ }^{64}$ Luis Cortavarria/Claudia Dziobek/Akihiro Kanaya/Inwon Song, "Loan Review, Provisioning, and Macroeconomic Linkages”, IMF Working Paper No 00/195 (2000), 11-12.

65 Andrea Enria, "The EU banking sector - risks and recovery. A single market perspective", Luxembourg, (2017), 16, <https://www.esm.europa.eu/speeches-and-presentations/esm-seminarandrea-enria-eba-chairperson> (accessed 29 July 2019).

66 Thomas Laryea, "Approaches to Corporate Debt Restructuring in the Wake of Financial Crises", International Monetary Fund, SPN/10/02 (2010), 26.

67 Stefan Ingves/Steven A. Seelig/Dong He, "Issues in the Establishment of Asset Management Companies", IMF Policy Discussion Paper PDP/04/3 (2004), 14.
} 
assurances to deposits and commit public resources to recapitalise banks. ${ }^{68}$ Political instability and economic fragility do not help the functioning of AMCs and the injection of public funds to manage NPLs under State guarantees can show appetites for bail-out plans. In this context, it has been argued that 'NPLs resolution is needed in order for banks to resume lending and the issues should be addressed with some form of central intervention, that is, government assistance'. ${ }^{69}$

Avgouleas and Goodhart proposed a new structure for a Pan-European "bad bank" with virtually ringfenced country subsidiaries to ensure burden sharing without debt mutualisation. ${ }^{70}$ This proposal has been echoed in the 2018 Commission blueprint on national $\mathrm{AMC}^{71}$ : the document provides non-binding principles to guide Member States in the implementation of AMCs at the domestic level. These principles highlight the role of AMC in removing troubled assets from banks' balance sheets and restructuring banks with high levels of NPLs. The blueprint suggests the need to complement the AMCs with the State aid rules, the Bank Recovery and Resolution Directive (BRRD) ${ }^{72}$ and the Single Resolution Mechanism ${ }^{73}$ to establish a common level playing field for resolving NPLs.

Baudino and Yun observed that 'effective communication on resolution measures are essential to provide clarity to market participants on the resolution tools and their timelines, build public support for the initiatives, and establish a reference point for ex post assessment of the NPL resolution strategy'. ${ }^{74}$ Converging towards a harmonised

\footnotetext{
${ }^{68}$ Rym Ayadi/Giovanni Ferri/Rosa M. Lastra, "Systemic Solutions to Systemic Crises. Dealing with NPLs in the Eurozone", European Economy 1 (2017), 158-159, <http://european-economy.eu/20171/systemic-solutions-to-systemic-crises-dealing-with-npls-in-the-eurozone/> (accessed 29 July 2019).

${ }^{69}$ Kalfaoglou (fn. 49), 173.

${ }^{70}$ Emilios Avgouleas/Charles Goodhart, "Utilizing AMCs to tackle Eurozone's legacy nonperforming loans", European Economy Banks, Regulation, and the Real Sector (2017), 103-104, <http://europeaneconomy.eu/wp-content/uploads/2017/07/EE_1.2017.pdf> (accessed 29 July 2019). On this discussion see also Campbell (fn. 59), 30-31.

${ }^{71}$ European Commission, "AMC Blueprint. Accompanying the document Communication from the Commission to the European Parliament, the European Council, the Council and the European Central Bank. Second Progress Report on the Reduction of Non-Performing Loans in Europe", Commission Staff Working Document, Brussels, SWD (2018) 72 final, <http://ec.europa.eu/finance/docs/policy/180314staff-working-document-non-performing-loans_en.pdf $>$ (accessed 29 July 2019).

${ }_{72}$ EU Bank Recovery and Resolution Directive (BRRD), Directive 2014/59/EU of the European Parliament and of the Council of 15 May 2014.

${ }^{73}$ The Single Resolution Mechanism (SRM) has been introduced by Regulation (EU) No 806/2014 of the European Parliament and of the Council of 15 July 2014 establishing uniform rules and a uniform procedure for the resolution of credit institutions and certain investment firms in the framework of a Single Resolution Mechanism and a Single Resolution Fund and amending Regulation (EU) No 1093/2010, OJ L 225 of 30 July 2014, p. 1.

${ }^{74}$ Patrizia Baudino/Hyuncheol Yun, "Resolution of non-performing loans - policy options", FSI Insights on policy implementation No 3 (October 2017), 4,

$<$ https://www.bis.org/fsi/publ/insights3.pdf> (accessed 29 July 2019).
} 
approach on recovery and resolution plans for NPLs represents a challenge for regulators and policymakers. ${ }^{75}$ This means that EU rules will have impact on where banks shed operations due to cost factors of maintaining operations and risk will likely migrate to less regulated local entities in a risk race to bottom. Barriers to the resolution of problem loans such as legal or economic impediments to collateral realisation may also result in the inability or unwillingness of banks to write loans off in a timely manner. This can result in a higher number of highly provisioned loans remaining on these banks' balance sheets.

\section{The restructuring of NPLs: the case of the Italian securitisation mechanism}

An example of resolving tools for NPLs is found in the Italian legislation (Law No $132 / 2015)^{76}$ that reformed the procedures for firms' liquidation and restructuring of assets. The law aims to increase the speed and efficiency of insolvency procedures and property foreclosures, and to promote higher recovery rates for creditors. In parallel, another legislative initiative concerning NPLs recovery (i.e. non-possessory pledge and foreclosure of collateral) has been launched with the Italian insolvency law reform of $2016 .^{77}$ The legal framework introduced the possibility to set private enforcement clauses in loan contracts with firms, allowing creditors to take ownership of collateral out-of-court in case of a debtor's default. ${ }^{78}$

The out-of-court enforcement procedures for secured loans granted to enterprises amend the "pactum marcianum" according to which the creditor takes over or dispose

\footnotetext{
${ }^{75}$ Vitor Constâncio, "Resolving Europe's NPL burden: challenges and benefits", Keynote speech at the event 'Tackling Europe's non-performing loans crisis: restructuring debt, reviving growth' (3 February 2017), <https://www.ecb.europa.eu/press/key/date/2017/html/sp170203.en.html> (accessed 28 July 2019).

${ }^{76}$ Italian Law No 132/2015 published in Italian OJ No 192 of 20 August 2015 that converted the Law Decree No 83/2015 published in Italian OJ No 147 of 27 June 2015, <http://www.gazzettaufficiale.it/atto/serie_generale/caricaDettaglioAtto/originario?atto.dataPubblicazi oneGazzetta=2015-08-

20\&atto codiceRedazionale $=15 \mathrm{G} 00136 \&$ is Anonimo $=$ false $\&$ normativi $=$ true $\&$ tipoVigenza $=$ originario $\&$ tipoSerie $=$ serie_generale \&currentPage $=1>($ accessed 29 July 2019) .

${ }^{77}$ Italian Law Decree No 59/2016 converted into Italian Law No 119/2016. For a commentary see Elisa Brodi et al., "New measures for speeding up credit recovery: an initial analysis of Decree Law 59/2016", Bank of Italy notes on Financial Stability and Supervision No. 4 (2016), 3-4, <https://www.bancaditalia.it/pubblicazioni/note-stabilita/2016-0004/no4-note-financialstability.pdf?language_id=1> (accessed 29 July 2019).

${ }^{78}$ European Commission, "Italy - Review of progress on policy measures relevant for the correction of Macroeconomic Imbalances" 13 (2016), <https://ec.europa.eu/info/files/italy-review-progress-policymeasures-relevant-correction-macroeconomic-imbalances-december-2016_en> (accessed 28 July 2019).
} 
the collateral but needs to compensate the debtor for any excess value of the collateral once the loan is satisfied. ${ }^{79}$ These rules reduce the court involvement and speed up the process of collecting bad assets: this would ease the agreement among creditors and enhance the marketability of NPLs. ${ }^{80}$ The law introduces provisions to facilitate access to finance for small and medium-sized enterprises (SMEs) enabling entrepreneurs to pledge movable assets while continuing to use them, and to enforce new non-possessory security interests over movable assets. The main aim of these provisions is to develop out-of-court restructuring arrangements in view of a timely resolution of firm's crisis.

The Italian out-of-court proceeding allows creditors of a firm that has filed for "concordato preventivo" to submit the restructuring plans in competition with the one presented by the firm. ${ }^{81}$ These reforms set a systematic approach in the resolution options to address bad loans, particularly in protecting creditors' interests to invest in distressed debts of viable firms and to pursue higher recovery rates. ${ }^{82}$ The rules on nonpossessory pledge and foreclosure of collateral can have a systemic impact in the restructuring of troubled banks as they can create legal certainty and confidence in the process of divesting NPLs portfolio. The ECB noted that 'the Italian supervisory regulation for NPLs is mainly principles-based with regard to the guidelines issued to banks on NPLs management practices'. ${ }^{83}$ The Italian government established a mechanism of double guarantees ${ }^{84}$ : the guarantee to collateralise liabilities and sell the senior tranches under the State backed-scheme 'GACS' 85 , and the guarantee to inject

\footnotetext{
79 José Garrido, "Insolvency and Enforcement Reforms in Italy", IMF Working Papers (2016), 8, $<$ https://www.imf.org/external/pubs/ft/wp/2016/wp16134.pdf> (accessed 29 July 2019).

${ }^{80}$ The Italian Insolvency law provides both in-court and out-of-court restructuring tools. See Monica Marcucci/Alessandra Pischedda/Vincenza Profeta, "The changes of the Italian insolvency and foreclosure regulation adopted in 2015", Bank of Italy Notes on Financial Stability and Supervision No. 2 (2015), 2. As observed, "faster and more efficient insolvency and foreclosure procedures will have a twofold effect on the stock of NPLs. In the short term, they should reduce the discount required by NPL buyers, with positive effects on NPL prices and on the perspective of development of a market for these assets'.

${ }^{81}$ Prior to the law reform, a firm filing for 'concordato preventivo' had the exclusive authority to submit a restructuring plan. The 'concordato preventivo' is an alternative procedure of the liquidation of enterprises, it allows creditors to participate actively in the sale of assets and, overall, in the reorganization process.

${ }^{82}$ José Garrido/Emanuel Kopp/Anke Weber, "Cleaning-up Bank Balance Sheets: Economic, Legal, and Supervisory Measures for Italy”, IMF Working Paper WP/16/135 (2016), 26-27.

${ }^{83} E C B$ (fn. 10), 87.

${ }^{84}$ The Italian Parliament enacted the Law No 49 of 14.2.2016, converting Law Decree No 18/2016 providing for a State Guarantee for NLPs securitisation transactions.

85 The Guarantee on Securitization of Bank Non-Performing Loans (GACS) introduced by Italian Law No 49/2016 is an aid-free scheme aiming to assist Italian banks in securitising and moving NPLs off their balance sheets. The State guarantee consists in remunerating the senior notes at market terms according to the risk taken, i.e. in a manner acceptable for a private operator under market conditions. The Ministry of Economy and Finance (MEF) can issue a GACS guarantee to secure the payment obligations of Italian
} 
capital by purchasing shares. Further, the State provides a double securitisation: (1) on the credit enhancement of senior notes; and (2) on the collateralised losses of the junior bondholders. ${ }^{86}$ The government guarantee should favour the coverage of gap between the net book value and the market value of the NPLs with the aim to improve the trade of bad loans. ${ }^{87}$ As argued, 'active NPL resolution measures are needed to bring NPL ratios on a firm downward trajectory over the medium term' ${ }^{88}$ The purpose of the GACS scheme is to involve a wide range of investors, stimulate banks to restructure NPLs and restore the necessary liquidity although the judicial and administrative inefficiencies experienced in Italy make the recovery process of NPLs extremely burdensome. ${ }^{89}$ The GACS, which is similar to the Greek "Hercules" asset protection scheme, aims to facilitate lenders remove bad debt by folding it into asset-backed securities. Like "Hercules" the GACS provides a private securitisation mechanism of non-performing loans without the use of State aid. It should be noted that the 'Rescue and Restructuring Guidelines' set out the principles under which the Commission evaluated the compatibility of State aid under Article 107(3)(c) of the TFEU. ${ }^{90}$ The Commission published in 2008-09 the 'Recapitalization Communication'"1 and 'Restructuring Communication' 92 for dealing with the conditions for compatibility of

Special Purpose Vehicles (SPVs) in relation to senior tranches of asset-backed notes issued by the SPVs within the securitisation transactions of NPLs according to the Italian securitisation law No. 130/1999. The Italian Law No 49/2016 allows for the provision of State guarantees for NPLs securitisation transactions that would contribute to alleviate the pressure on banks' balance sheets.

${ }^{86}$ The Italian law does not require the consent of the borrower for the sale of a loan, only the notification of the borrower. Article 58 of the Italian Banking Act (No 385/93) provides an exemption from the obligation to notify each debtor in the case of a bulk loan sale.

87 John Fell/Claudiu Moldovan/Edward O'Brien, "Resolving non-performing loans: a role for securitisation and other financial structures?", ECB Financial Stability Review, Special features (May 2017), 158.

${ }^{88}$ Kamiar Mohaddes/Mehdi Raissi/Anke Weber, "Can Italy grow out of its NPL overhang? A panel threshold analysis", Economics Letters 159 (2017), 186.

${ }^{89}$ Giorgio Barba Navaretti/Giacomo Calzolari/Alberto Franco Pozzolo, "Getting rid of NPLs in Europe" European Economy 1 (2017), 11, fn. 4, <http://european-economy.eu/2017-1/getting-rid-of-npls-ineurope/> (accessed 11 October 2019).

${ }^{90}$ European Commission communication, "Guidelines on State aid for rescuing and restructuring nonfinancial undertakings in difficulty”, C (2014) 4606/2,

<https://ec.europa.eu/competition/state_aid/legislation/rescue_resctructuring_communication_en.pdf> (accessed 21 October 2019). In principle, EU law prohibits State aid unless it is allowed in very limited circumstances being in the kind and amounts of aid that pursue common policy and do not cause excessive distortion in the markets.

${ }^{91}$ European Commission communication, "The recapitalisation of financial institutions in the current financial crisis: limitation of aid to the minimum necessary and safeguards against undue distortions of competition", C (2008) 8259 final,

<http://ec.europa.eu/competition/state_aid/legislation/recapitalisation_communication.pdf> (accessed 21 October 2019).

92 European Commission communication "on the return to viability and the assessment of restructuring measures in the financial sector in the current crisis under the State aid rules" (2009/C 195/04), 
State capital injections. The amount of guarantee needs to comply with the European Commission's guidelines on State aid and, generally, is limited to the necessary restoration of the financing capacity. However, the recent episodes of bank collapses (e.g. Banca Popolare di Vicenza and Veneto banca) showed that the interaction between State aid rules and national insolvency law is not well defined and there might be risk of unfair practices in the choice of viable restructuring options. ${ }^{93}$

The Italian and Greek schemes can be considered a step forward in the resolving tools of deteriorated assets: these market-based measures enhance private incentives to expedite the reduction of NPLs and mitigate the risk of banks failure. However, the European Banking Authority (EBA) has warned that the securitisation mechanisms face regulatory constraints due to 'very high capital requirements on investor credit institutions under the CRR, compliance challenges as regards certain risk retention and due diligence requirements under the Securitisation Regulation' ${ }^{94}$ The solution adopted by the Italian regulatory authorities to address the NPLs issue is a welcome approach in the current legislative framework even if the guarantees mechanism seems an accounting makeup - as the losses cannot disappear - rather than a full definition of problems. The Commission stated that 'the State guarantee on the senior tranche will only become effective, if at least more than half of the non-guaranteed and risk-bearing junior tranche has been successfully sold to private market participants' ${ }^{95}$

The GACS system to resolve NPLs raises complex challenges linked to the market conditions: a restructuring mechanism that reflects a regulatory compromise where the guarantees could be activated at the expenses of taxpayers' money. Whether the GACS scheme represents a viable option to resolve problematic loans, criticisms arise about the public intervention's potential negative incentives, which refer to 'the reduction of banks' loan-monitoring tools, the reduction of banks' efforts to develop efficient procedures to internally work out NPLs and the increase of banks' risk-taking

\footnotetext{
<http://eur-lex.europa.eu/legal-content/EN/ALL/?uri=CELEX:52009XC0819\%2803\%29> (accessed 21 October 2019).

${ }^{93}$ Michael Schillig, BRRD/SRM, corporate insolvency law and EU State aid - the trifurcated EU framework for dealing with banks in distress, in: Gianni Lo Schiavo (ed.), The European Banking Union and the Role of Law, 2019, p. 256-257.

94 EBA, "Opinion of the European Banking Authority to the European Commission on the Regulatory Treatment of Non-Performing Exposure Securitisations", EBA-Op-2019-13 (23 October 2019), 2-3, <https://eba.europa.eu/eba-publishes-opinion-regulatory-treatment-non-performing-exposuresecuritisations $>$ (accessed 23 October 2019).

${ }^{95}$ European Commission, "State aid: Commission approves impaired asset management measures for banks in Hungary and Italy", IP/16/279 (10 February 2016), <http://europa.eu/rapid/press-release_IP16-279_en.htm> (accessed 29 July 2019).
} 
behaviour' ${ }^{96}$ Further, macroeconomic conditions and macro-financial vulnerabilities (i.e. high sovereign debt, fragile banking system and poor economic growth) impede swift NPL workout and resolution. ${ }^{97}$ According to the Commission, the GACS mechanism is an important component of Italy's strategy to tackle asset quality problems and has already made a significant contribution in moving NPLs off from the banks' balance sheet. ${ }^{98}$ Specifically, it is reported that 'between February 2016 and November 2018 the securitisation scheme has been used seventeen times, removing $€ 51$ billion (gross book value) of NPLs from the Italian banking system, which corresponds to almost two thirds of the total reduction of non-performing loans in Italy during that period'. 99

In this context, the EU Commission published a proposal for a directive on minimum procedures for out-of-court settlement regarding NPLs. ${ }^{100}$ The proposal links the various supervisory initiatives taken by the Single Supervisory Mechanism (SSM) and EBA to address the NPLs issue. ${ }^{101}$ The proposal aims (1) to foster the debt recovery procedures through the implementation of a distinct common accelerated extrajudicial collateral enforcement procedure; and (2) to create secondary markets for NPLs. ${ }^{102}$ The

\footnotetext{
96 Eleonora Broccardo/Maria Mazzuca, "Can 'public' market-based solutions restore the banking system? The case of non-performing loans (NPLs)", Public Money \& Management 37 (2017), 518.

${ }^{97}$ Sharon Donnery, "NPL workout and resolution in the euro area", Speech at the Peterson Institute for International Economics, Washington DC, 6 October 2016, 1-2,

<https://www.bis.org/review/r161010a.pdf> (accessed 12 October 2019).

${ }^{98}$ European Commission, "State aid: Commission approves prolongation of Italian guarantee scheme for non-performing loans", SA.53518 (2019/N), OJ C 277 of 16 August 2019,

<https://ec.europa.eu/competition/elojade/isef/index.cfm?fuseaction=dsp_result\&policy_area_id=1,2,3

$>$ (accessed 18 October 2019).

${ }^{99}$ Ibid.

${ }^{100}$ European Commission, "Proposal for a Directive of the European Parliament and of the Council on credit servicers, credit purchasers and the recovery of collateral", Brussels, COM (2018) 135 final, $<$ https://ec.europa.eu/info/law/better-regulation/initiatives/com-2018-135_en> (accessed 27 July 2019).

101 European Banking Authority, "Guidelines on common procedures and methodologies for the supervisory review and evaluation process (SREP)", EBA/GL/2014/13 (19 December 2014). See also ECB, "Addendum to the ECB Guidance to banks on nonperforming loans: supervisory expectations for prudential provisioning of non-performing exposures" (March 2018), 10-11, 〈https://www.bankingsupervision.europa.eu/ecb/pub/pdf/ssm.npl_addendum_201803.en.pdf>

(accessed 30 July 2019); ECB, "Addendum to the ECB Guidance to banks on nonperforming loans: Prudential provisioning backstop for non-performing exposures" (October 2017), 2,

<https://www.bankingsupervision.europa.eu/legalframework/publiccons/pdf/npl2/ssm.npl_addendum_ draft_201710.en.pdf> (accessed 29 July 2019); ECB, "Guidance to banks on non-performing loans", (March 2017), 49-50,

<https://www.bankingsupervision.europa.eu/ecb/pub/pdf/guidance_on_npl.en.pdf> (accessed 30 July 2019); ECB, "Stocktake of national supervisory practices and legal frameworks related to NPLs" (June 2017),

<https://www.bankingsupervision.europa.eu/ecb/pub/pdf/ssm.stock_taking2017.en.pdf> (accessed 29 July 2019).

102 Carla Stamegna, "Credit servicers, credit purchasers and the recovery of collateral. Fostering secondary markets for non-performing loans (NPLs) and easing collateral recovery", European
} 
overall objective is to reduce the burden of NPLs in the banks' balance sheet by introducing efficient out-of-court procedures to recover value from collateral and to lower the costs for resolving NPLs making them more competitive in the market. ${ }^{103}$ The out-of-court procedures are a better option than going to court as they might avoid the length of court proceedings, particularly in Southern Italy where a large part of the NPLs are located. ${ }^{104}$ On this view, it has been observed that 'the delays and widespread obstacles to court and out-of-court settlement of disputes are in fact a very important reason for the very high stock of NPLs in banks' balance sheets'. ${ }^{105}$ The establishment of out-of-court procedures, expediting the timeline for debt restructuring, incentivises the NPL sale and reduces creditors' losses. ${ }^{106}$

The need to ensure consistency in the restructuring mechanisms and to create a harmonised insolvency regime has been recognised by the EU Council in the action plan for non-performing loans. ${ }^{107}$ The Council underlines the opportunity to set common principles and harmonised key elements of insolvency law such as minimum standards for secured creditors protection. ${ }^{108}$ As a result, the EU Council has expressed a supportive position towards the ECB and Commission policies to enhance a prudential regulatory treatment of bad loans. ${ }^{109}$ On this view, it has been argued that

\footnotetext{
Parliamentary Research Service 2019), 6-7, <http://www.europarl.europa.eu/RegData/etudes/BRIE/2019/635514/EPRS_BRI(2019)635514_EN.pdf $>$ (accessed 29 July 2019).

103 Alexander Lehmann, "Risk reduction through Europe's distressed debt market", Bruegel Policy Contribution Issue No 02 (18 January 2018), 5-6, <http://bruegel.org/wp-content/uploads/2018/01/PC02_2018-100118.pdf> (accessed 28 July 2019).

${ }^{104}$ The Economist, "Bad loans remain a concern in Italy and across southern Europe", (26 May 2018), <https://www.economist.com/finance-and-economics/2018/05/26/bad-loans-remain-a-concern-in-italyand-across-southern-europe > (accessed 19 October 2019).

105 Ignazio Visco, "Workshop on Stability of the Banking System", Keynote speech at the European University Institute, Florence, 5 May 2016, <https://www.bancaditalia.it/pubblicazioni/interventigovernatore/integov2016/visco-050516.pdf> (accessed 20 October 2019).

${ }^{106}$ Marcel Magnus/ Alienor Anne Claire Duvillet-Margerit/Benoit Mesnard/Christina Katopodi, "Nonperforming loans in the Banking Union: state of play", European Parliamentary Research Service (13 July 2017), 2 ,

<http://www.europarl.europa.eu/RegData/etudes/BRIE/2017/602072/IPOL_BRI(2017)602072_EN.pdf $>$ (accessed 20 October 2019).

107 ECOFIN Council, "Action Plan to Tackle Non-Performing Loans in Europe", 11173/17 (11 July 2017), 3, <http://data.consilium.europa.eu/doc/document/ST-11173-2017-INIT/en/pdf> (accessed 29 July 2019).

${ }^{108}$ ECOFIN Council, "Report of the FSC Subgroup on Non-Performing Loans", 9854/17 (31 May 2017), 61, <http://data.consilium.europa.eu/doc/document/ST-9854-2017-INIT/en/pdf> (accessed 27 July 2019).

${ }^{109}$ European Council, "Non-performing loans: Council approves position on capital requirements for banks' bad loans", Press Release 594/18 (2018), <https://www.consilium.europa.eu/en/press/pressreleases/2018/10/31/non-performing-loans-council-approves-position-on-capital-requirements-forbanks-bad-loans/?utm_source=dsms-auto\&utm_medium=email\&utm_campaign=Non-
} 
ex-ante measures - such as tightening of bank supervision and strengthen of capital requirements together with developing internal NPL management skills - can effectively help banks to overcome the non-performing exposures problem. ${ }^{110}$

The Council's initiatives have been reinforced in the Communication on the 'Reduction of Non-Performing Loans in Europe' where it is suggested for banks to hold sufficient loan loss coverage for newly originated loans if these become distressed exposures. ${ }^{111}$ It is pointed that the problem of NPL could be addressed by monitoring the temporal triggers in contracts, specific cash flow impaired (i.e. principal, interest past due) and collateral value. In this direction seems oriented the Commission's proposal for a directive to establish a 'preventive restructuring frameworks' for financially distressed firms. ${ }^{112}$ This proposal complements the 2015 EU Insolvency Regulation $^{113}$ and aims to harmonise pre-insolvency restructuring mechanisms for NPLs among Member States. It also intends to incentivise firms to reduce the volume of non-performing assets although 'it creates a refuge for failing firms that should be liquidated'. ${ }^{114}$ However the proposal does not define the ranking of claims (particularly for banks holding NPLs with collateral) in pre-insolvency proceedings which constitutes a serious flaw that can undermine the objectives of directive.

\section{Conclusion}

The monitoring and classification of NPLs represent a major challenge for supervisory authorities and bank regulators: the accumulation of deteriorated assets affects the

performing+loans $\% 3 \mathrm{a}+$ Council+approves+position+on+capital+requirements+for+banks $\% 27+$ bad+loa ns> (accessed 28 July 2019).

${ }^{110}$ Anastasiou Dimitrios, "Management and Resolution methods of Non-performing loans: A Review of the Literature" (2016), 12-13, <https://ssrn.com/abstract=2825819> (accessed 10 October 2019).

${ }^{111}$ EU Commission, "Communication from the Commission to the European Parliament, the Council and the European Central Bank. Second Progress Report on the Reduction of Non-Performing Loans in Europe", COM (2018) 133 final, 8, <http://ec.europa.eu/finance/docs/policy/180314-communicationnon-performing-loans_en.pdf> (accessed 29 July 2019).

112 EU Commission, "Proposal for a Directive of the European Parliament and of the Council on preventive restructuring frameworks, second chance and measures to increase the efficiency of restructuring, insolvency and discharge procedures and amending Directive 2012/30/EU", COM (2016) 723 final, <http://ec.europa.eu/information_society/newsroom/image/document/2016-48/proposal_40046.pdf> (accessed 29 July 2019).

113 Regulation (EU) 2015/848 of the European Parliament and of the Council of 20 May 2015 on insolvency proceedings (OJ 2015 L 141, p. 19).

114 Horst Eidenmüller, "Contracting for a European Insolvency Regime", European Business Organization Law Review 18 (2017), 276. 
liquidity and lending activities of firms which lead to potential systemic risk. The implications of NPLs in the financial markets can turn into banking failures and economic losses particularly at times of crisis. ${ }^{115}$ This is exacerbated by a lack of harmonised treatment of non-performing exposures and absence of coordination in the resolving policies. Specifically, the resolution toolkit varies among national competent authorities raising uncertainty on the viable strategy for distressed loans. Convergence of supervision, common accounting and regulatory practices are necessary to solve the NPL problem. This problem is even more complicated because of lack of consolidation among data and information disclosure that should be the primary source to identify the deterioration of asset at an early stage.

Various proposals to restructure NPLs have been advanced in the banking industry however harmonisation of the restructuring practices appears the way forward to prevent the origination of bad loans. The fact that resolving tools are essentially left to the domestic insolvency laws is regarded as a manifestation of the principle of subsidiarity ${ }^{116}$ : this allows for national experiments and flexibility for the development of tailored solutions adopted to the needs of local banking sector. ${ }^{117}$ Such approach seems justified by the absence of a minimum degree of coordination between the restructuring tools available in the Banking Union (i.e. SRM and BRRD) and insolvency regimes. ${ }^{118}$ This lack of consistency creates a grey area in which the loopholes for public financial support can affect the reorganisation actions among failing banks. The fragility of EU banking sector and the weaknesses of the credit channel showed the systemic risk of NPLs. ${ }^{119}$ New regulations have been introduced at the national level to reduce the fragmentation of insolvency regimes although these regulatory responses leave wide discretion to supervisory authorities. The establishment of AMCs shows perilous reliance to public support which can lead to State intervention and opportunistic bail-out plans. On this view, the resolution

\footnotetext{
115 Bottazzi/De Sanctis/Vanni (fn. 5), 3.

116 The concept of subsidiarity is defined as 'the guiding principle on the exercise of legislative powers by the EU institutions in areas in which both the EU and the member states share legislative competences'. See on this point Federico Fabbrini, The Principle of Subsidiarity in: Takis Tridimas and Robert Schütze (eds.), Oxford Principles of EU Law, Vol. 1, The European Union Legal Order, 2018, p. 221.

117 Jens-Hinrich Binder, "The Relevance of the Resolution Tools Within the SRM", EBI Working Paper Series No. 29/2018, 10, <https://ssrn.com/abstract=3274520> (accessed 19 October 2019).

118 The BRRD does not regulate bankruptcy or insolvency proceedings which remain in the sphere of national competence as an alternative measure to resolution.

${ }^{119}$ Nadege Jassaud/Edouard Vidon, "European NPLs through the crisis: A policy review", Journal of Financial Regulation and Compliance 25 (2017), 416.
} 
framework should be combined with effective restructuring programmes such as private workouts, preventive measures and ad hoc units for monitoring non-performing assets. However in the absence of harmonised resolving tools among credit institutions, it seems difficult to adopt a common approach of restructuring mechanisms for NPLs. 